\title{
O VÉU DA NOITE QUE (DES)COBRE O DESEJO DE BICHAS E "HETEROS" NO CAMPO DO PALMEIRAS, EM CUBATI - PB
}

\author{
AZEMAR DOS SANTOS SOARES JÚNIOR \\ Doutor em Educação pela Universidade Federal da Paraíba (UFPB) e docente no \\ Departamento de Práticas Educacionais e Currículo da Universidade Federal do Rio \\ Grande do Norte (UFRN). \\ E-mail: azemarsoares@hotmail.com \\ ORCID: https://orcid.org/0000-0003-0015-415X
}

\begin{abstract}
WALBER FERREIRA DA SILVA
Mestre em História pela Universidade Federal de Campina Grande (UFCG), graduado em História pela mesma universidade. Professor da rede básica de ensino do município de Cubati - PB.

E-mail: walberfs_4@hotmail.com ORCID: https://orcid.org/0000-0002-4426-8207
\end{abstract}

\begin{abstract}
RESUMO: Este texto trata sobre as homossexualidades numa perspectiva do interior nordestino, tendo como recorte espacial a cidade de Cubati-PB entre os anos de 2011 e 2015. A investigação se dá, a partir do encontro de cinco bichas, que construíram laços de solidariedades, produzindo uma estética da existência, tendo a amizade, como modo de vida. No texto, usamos das fontes orais que foram submetidas a análise do discurso aos moldes de Michel Foucault (2012). A pesquisa postula a possibilidade das bichas do interior nordestino criarem táticas que subvertem os padrões cisheteronormativos, inventando novas possibilidades de viver relações afetivas, amorosas e sexuais, driblando a vigilância panóptica e disciplinadora de corpos subalternizados.
\end{abstract}

PALAVRAS-CHAVE: Bichas; Estética da existência; Amizade. 


\title{
THE VEIL OF THE NIGHT THAT (DIS)COVERS THE DESIRE OF PIGS AND "STRAIGHT" IN CAMPO DO PALMEIRAS, IN CUBATI - PB
}

\begin{abstract}
This text deals with homosexualities from a perspective of the northeastern interior, having the city of Cubati-PB as a spatial cutout between 2011 and 2015. The investigation takes place from the encounter of five queers, who built bonds of solidarity, producing an aesthetic of existence, with friendship as a way of life. In the text, we use oral sources that were subjected to discourse analysis along the lines of Michel Foucault (2012). The research postulates the possibility that queers from the northeastern interior create tactics that subvert cisheteronormative patterns, inventing new possibilities for living affective, loving and sexual relationships, circumventing the panoptic and disciplining surveillance of subalternized bodies.
\end{abstract}

KEYWORDS: Faggots; Aesthetics of existence; Friendship.

Recebido em: 30/06/2021

Aprovado em: 08/11/2021

DOI: http://dx.doi.org/10.23925/2176-2767.2021v72p205-227 


\section{Introdução}

"O homem que diz dou. Não dá. Porque quem dá mesmo, não diz.

O homem que diz vou, não vai. Porque quando foi já não quis.

O homem que diz sou, não é. Porque quem é mesmo é, não sou. O homem que diz "tô", não "tá". Porque ninguém "tá" quando quer.

Coitado do homem que cai No Canto de Ossanha, traidor

Coitado do homem que vai Atrás de mandinga de amor.

Vai, vai, vai, vai. Não vou

Não vou, que eu não sou ninguém de ir, em conversa de esquecer

A tristeza de um amor que passou. Não, eu só vou se for pra ver

Uma estrela aparecer, na manhã de um novo amor.

Amigo, senhor sarava, Xangô me mandou lhe dizer

Se é Canto de Ossanha não vá, que muito vai se arrepender.

Pergunte pro seu Orixá, o amor só é bom se doer

Pergunte pro seu Orixá, o amor só é bom se doer

Vai, vai, vai, vai, amar

Vai, vai, vai, vai, sofrer

Vai, vai, vai, vai, chorar

Dizer, que eu não sou ninguém de ir

Em conversa de esquecer, a tristeza de um amor que passou Não, eu só vou se for pra ver, uma estrela aparecer Na manhã de um novo amor"l.

A historiografia foi durante muito tempo, masculina. Quase sempre considerou os homens e mesmo quando começou a pensar as mentalidades, pelos idos anos 1980 e até mesmo a terceira geração dos Annales, não considerou ou considerou pouco a história das homossexualidades e das dissidências sexuais e de gênero. Esse silenciamento dos sujeitos LGBTQIAP+, sobretudo no Brasil, tem sido quebrado, por historiadoras/es que, apesar de, não falarem de si diretamente, usam de suas vozes e escritas dissidentes, para fazer ecoar outras vozes, outrora silenciadas. Apesar de "ainda ocupar um lugar marginal na produção histórica" (VERAS, 2014, p. 92), escrever uma história sobre bichas $^{2}$, se faz necessário para o fortalecimento de uma produção historiográfica que não deseja Clio em silêncio.

O presente artigo é fruto de uma pesquisa desenvolvida no campo da investigação sobre a História Cultural das práticas educativas e das

\footnotetext{
1 "O Canto de Ossanha": Música de Baden Powel e Vinícius de Moraes.

2 Segundo Green (2019), "bicha" foi um termo criado nos anos 1930, para atribuir sentido ao homem efeminado que mantém relações sexuais com outros homens. Ainda hoje, o termo é usado de forma pejorativa ao referir-se a gays, no entanto, fazemos uso do termo, dentro de uma perspectiva queer, questionando a injúria, se apropriando do xingamento, dando a ele o empoderamento que esses sujeitos hoje conseguem ter e a partir disto, se reconhecer e se dizer como bichas.
} 
sociabilidades, pensando a cidade de Cubati ${ }^{3}$, no interior da Paraíba, como um lugar de produção de práticas, de discursos, de sujeitos e suas tecnologias corporais. Nessa perspectiva, buscou-se a partir do relato de sujeitos que se reconhecem como "bichas", analisar como a amizade, enquanto modo de vida, colaborou para a construção de táticas que, tiravam-Ihe da condição de um assujeitamento passivo. Lutas e tensões em torno de suas sociabilidades, produziam sujeitos preocupados com um cuidado de si, numa construção de uma estética da existência de bichas do interior da Paraíba. Para tanto, tomamos de empréstimo as formas de analisar discursos na ordem proposta por Michel Foucault (2012) que entender a produção de enunciados como a composição de um arquivo que será meticulosamente lido e interpretado gestando outros enunciados, que aqui chamamos de história.

Há uma seara de pesquisas sobre as homossexualidades, sendo estudadas a partir do recorte das grandes cidades ou capitais, sobretudo as do sudeste brasileiro. Há de se reconhecer a contribuição do trabalho de James Green (2019), que no espectro de uma acurada pesquisa, demonstrou que as bichas, sobretudo na década de 1950, saíram de perto do seio familiar, muitas delas do Nordeste, para tentar "ganhar a vida" em São Paulo ou Rio de Janeiro. Tanto suas cidades, não ofereciam condições para seu crescimento profissional e econômico, como elas usavam dessa migração, para "sair do armário", ainda que este armário fosse uma presença formadora de sua identidade (SEDGWICK, 2007) e estando presente em suas subjetividades e sensibilidades em sua trajetória de vida.

As bichas aqui encarnadas e escritas, formam um grupo de amigas. Seus nomes foram ocultados, preservando suas identidades que passaram a ganhar nomes inspirados, na obra literária de Caio Fernando Abreu, a saber: Jacira, Telma, Irma, Irene e Dulce. Essas, não são as mesmas das histórias narradas na ficção do autor sulista. As que estão presentes neste texto, tem suas próprias idiossincrasias, compondo uma outra estética da existência, mais rural, menos urbana. Uma estética que, usa do mato e lajedos, composição da paisagem natural da cidade e região, para a produção de suas táticas, escapando do olhar panóptico (FOUCAULT, 1987) daqueles que

\footnotetext{
3 Cubati é um município brasileiro do estado da Paraíba, localizado na Região Geográfica Imediata de Campina Grande. Possui população estimada pelo IBGE (Instituto Brasileiro de Geografia e Estatística) no ano de 2016, de 7.234 habitantes e Área territorial de 137,2 km².
} 
querem moldar seus corpos dentro do padrão de uma masculinidade hegemônica (CONNELL; MESSERSCHIMIDT, 2013) presente nas cidades do interior nordestino, sobretudo a Paraíba, recorte desta pesquisa.

Dadas as especificidades e diferenças de recorte temporal e geográfico das bichas de James Green (2019) e considerando a possibilidade das muitas exceções, que porventura pudessem existir em meados do século XX, Dulce, Irma, Irene, Telma e Jacira, não fizeram grandes migrações, ficaram em seu sublime torrão, por várias razões. O Nordeste do século XXI, é uma outra região, não mais aquela construída a partir dos discursos da seca e da fome que, solapavam a existência dos sujeitos que aqui viviam. Apesar das migrações continuarem existindo desses sujeitos, que tentam construir outras estéticas da existência, fora de sua cidade no interior nordestino, neste lugar, repousa ainda, uma masculinidade hegemônica que não dá a vez ou voz às bichas.

Aquelas que não tiveram oportunidades de viver sua sexualidade em outras cidades maiores, sendo apresentadas a outras subculturas gays, tiveram que ser inventivas para driblar a norma, suposição essa que, fazemos por não termos dados que evidenciem suas táticas e vivências, elas foram silenciadas, dentro de suas cidades, dos espaços sociais que grassavam práticas educativas da sexualidade, como o machismo e a homofobia, fazendo-Ihes de suas existências, corpos e sensibilidades dobrados e engavetados em seus armários. Desta maneira, o silêncio de Clio se fez presente, no interior nordestino, com esses sujeitos que saíram timidamente do armário concomitante a um saber histórico também interditado em seu armário (ALBUQUERQUE JR, 2019) que repudia histórias que não sejam misóginas, que não sejam sangrentas, de lutas ou revoluções, que não falem de corpos abjetos, que não falem da intimidade de sujeitos que se aproximam do feminino, que repudiam o uso de palavras que façam parte do cotidiano desses sujeitos abjetos.

Neste século XXI, as bichas continuam saindo do interior nordestino e conhecendo subculturas gays em lugares como São Paulo ou Rio de Janeiro, mas também fazem outros movimentos dentro do Nordeste, como o que Dulce, um dos sujeitos da pesquisa, fez. Ela saiu de Campina Grande, sua cidade natal, para trabalhar como professora de história em Cubati, separadas por 83 quilômetros de uma estrada que nem sempre, fora asfaltada. Ao chegar 
na região do Curimataú, ela construiu laços de sociabilidade com suas alunas que ultrapassaram os muros da escola, onde se conheceram e aqui estão seus relatos de uma vida bicha, de uma vida abjeta, mas agora objetos de uma pesquisa de história.

\section{O abrir do armário na casa das bonecas}

Era tarde. Passava das 23 horas. Dulce e Irene, estavam no terraço de sua casa, quando apareceu dois "esquemas" para elas, naquela noite. A rua estava silenciosa, poucas pessoas pela praça. Ninguém perto da "casa das bonecas", a não ser os dois rapazes que queriam "curtir" uma noite com as bichas, aliviar seu gozo, de forma silenciosa, invisível. A negociação da subida deles a casa delas, foi cercada de tensão, porque não havia porta escondida, a entrada era visível, para qualquer transeunte que estivesse nas imediações da praça. De seus corpos vestidos, saltavam aos nossos olhos, seus membros em riste, sendo tocados por cima de suas bermudas. Seus corpos falavam de seu desejo, com seus falos enrijecidos, que deixavam escapar seu ideal inconsciente, embora historicamente construído, de que nós, bichas afeminadas, estávamos à procura do que eles tinham para nos oferecer, um pau grande que preenchesse nossas "cloacas".

Tanto Dulce e Irene, quanto os rapazes bissexuais enrustidos, mostravam seus corpos sinuosos, demarcando lugares sociais e posições de assujeitamento, na cidade. Seus lugares sociais eram evidenciados, por serem duas professoras, moradoras do centro de uma cidade do interior paraibano, enquanto os rapazes, vaqueiros e moradores de um sítio da região. Seus corpos assujeitados eram evidenciados por sua identidade de gênero, francamente assumida. Os vaqueiros também sofriam algum tipo de assujeitamento, porque tinham a intenção de manter sua bissexualidade no anonimato. Dito de outra forma, o termo "bissexualidade" não pode ser visto como uma categoria estanque, sobretudo porque aqueles que fizeram sexo

\footnotetext{
${ }^{4}$ Gíria local que dá a ideia de encontros sexuais.

${ }^{5}$ A casa de Dulce, era assim chamada pejorativamente, pelos citadinos, em referência ao trânsito desses sujeitos abjetos para a população cubatiense.

${ }^{6}$ Entre bichas, brincávamos sobre quem eram as mais guerreiras, quem gostava ou aguentava um pau grande, assim elas diziam que seu cu era tão pequeno quanto de uma galinha, caindo muitas vezes no riso desmedido.
} 
com as bichas e não se reconheciam com gays, estão sujeitos, a partir de seus papeis sexuais, ou mesmo sua performatividade de gênero, cuja verbalização de uma heterossexualidade era reafirmada como um pleonasmo, por acreditarem não ser gays, porque "comiam" as bichas. James Green (2019) identificou em sua pesquisa que, o binarismo presente na díade homem/bicha, fazia parte do cotidiano de sujeitos de origens mais humildes, enquanto homossexuais urbanos de classe média, se reconheciam como gays, tal levantamento levou-o a considerar que, as muitas maneiras de se vivenciar as homossexualidades viviam em intersecção com uma certa bissexualidade não assumida de sujeitos que performavam uma heterossexualidade, casando-se com uma mulher, no entanto seu desejo fluía para além do que seus corpos mostravam em público.

Se para gays, sair do armário era um processo doloroso que gerava fraturas em suas existências, sujeitos com tendência à bissexualidade ${ }^{7}$ viviam situação semelhante, talvez com peso ainda maior, sobretudo ao pensar a violência simbólica que eles sofreriam, se revelado o seu segredo inconfesso, numa cidade do interior nordestino, cujas normas de gênero, que inauguram e costuram seus corpos, enquanto sujeitos, e que nesse recorte geográfico, tais normas são potencializadas. Em outras palavras, se descobertos, os vaqueiros, não seriam apontados como bissexuais, mas como bichas, "viados", "baitolas", "queima rosca", para ficar nesses exemplos que comumente são ditos, na cidade. A fluidez desses sujeitos, quanto a sua performatividade de gênero, confundia os citadinos, bagunçando a hierarquia de gênero e o binarismo que sempre assujeitou seus corpos.

O mesmo dispositivo de sexualidade que fazia os rapazes soltarem o verbo, dizer aos seus parceiros o que fizeram ou não com gays com quem tinham relações sexuais, como uma exibição de um troféu levantado, por ter desonrado a masculinidade de outros rapazes gays, também suscitava desconfianças, dúvidas, sobre quais papeis de gênero, eles executaram com elas. Dito de outra maneira, a "curtição" ou "putaria", adjetivos que nomeavam suas práticas educativas da sexualidade, não eram aceitas por alguns de seus

\footnotetext{
7 Considerando o caráter subjetivo da formação do sujeito, não quero afirmar que eles são bissexuais ou gays, sugerindo uma "tendência", considerando que nós e eles (os vaqueiros), sabíamos tanto de seu desejo praticado, tanto com homens, no anonimato, quanto com mulheres, socialmente escancarado.
} 
interlocutores, que indagavam sobre seus papeis de gênero, praticados com os gays. Afinal eles "deram" ou "comeram" as bichas? Responder a esta pergunta panóptica, garantia ao vaqueiro e seu amigo, o lugar social que lhes era imputado.

Assim, a tentativa de fazer os vaqueiros subirem a casa das bichas, era marcada por uma reafirmação de uma hierarquia de gênero, explicitada por códigos não verbais, gestos, que deixavam claro, o que Ihes propunham ao massagear sobre a roupa, seus paus. Negando a possibilidade de elas "comerem" seus monossílabos rústicos. Sobre essa hierarquia de gênero, Murillo Nonato (2020), numa perspectiva butleriana, dizia que sobre os corpos, é imposta uma coerência do sexo-gênero, a partir das regras da cisheteronormatividade e quando as expressões desses corpos, vestimentas e maneirismos não são refletem tal disciplinarização, as sanções começam a ser colocadas para esses dissidentes.

O conceito de bissexualidade era totalmente estranho aos vaqueiros. Para eles, gays eram apenas, os "viados" que eles, os heteros, queriam "comer", demarcando uma fronteira, ainda que sua coerência quanto ao sexo-gênero, não houvesse, porque enquanto afeminadas, as bichas eram a "ficção" de corpos femininos que eles buscavam, ou ao menos, era isso que eles tentavam nos dizer, por gestos e poucas palavras. Quando os dois, pensaram em vencer ao medo em nome do desejo, subiram a escada. Sem conhecer a geografia do interior da residência das bichas, eles achavam que tinha uma porta, que pudessem adentrar sem ser vistos, no entanto, para chegar ao "primeiro", ao subir dos degraus, havia um corredor gradeado, que dava acesso à porta da sala, e que ficava de frente com a praça.

Sabendo dos riscos de possíveis sanções sociais, por estarem descumprindo o assujeitamento ao qual era imputado aos seus corpos, os vaqueiros declinaram de sua decisão de manter o contado íntimo com os rapazes gays, sentados nos batentes da escada, ensimesmados, decidiram descer as escadas, e num tom monossilábico, propuseram a elas transar no mato, depois do Campo do Palmeiras. O medo, vencia o desejo, tanto da parte deles, quanto das bichas. Eles temiam à luz, a visibilidade da praça. Elas temiam a escuridão noturna, a brenha, bichos notívagos e até mesmo a eles, os vaqueiros. Assim, resolveram não ir para o mato, bem como eles também não entraram na casa delas. Ao ir embora, Dulce e Irene, acenderam um 
baseado e ficaram comentando o ocorrido, como geralmente fazíamos depois do sexo com os rapazes da cidade ou com a ausência deles, como acontecera naquela noite.

Durval Muniz de Albuquerque Jr. (2003), pensando a partir da obra freyriana e os discursos formadores do homem nordestino, diz que o advento da luz elétrica trouxe para o Nordeste, a imposição de se viver às claras, ainda que essa mudança ética, também tenha trazido o dissabor do desmantelamento das famílias, uma vez que, a luz também mostrava as traições, os maridos deixando suas esposas solitárias em suas camas, na calada da noite, para manter outras relações, que mesmo não sendo ditas, mantendo-se em segredo, eram flagradas pela claridade da luz elétrica.

Bichas afeminadas, eram a representação dessa cidade femininizada e iluminada, revelada quanto ao nosso desejo. Sobre esses sujeitos, aparentemente não havia sombras ou mistérios para os vaqueiros, entretanto, eles queriam preservar sua auto propalada hierarquia de sexo-gênero, na calada da noite, por trás das folhas dos arbustos e árvores do campo do Palmeiras. Depois daquela noite frustrada, um dos vaqueiros, sempre passava na frente da casa de Dulce, montado em seu cavalo, que se mostrava presente, com o toque dos seus cascos, no calçamento da rua, quando ouvia esse som, ia ao terraço, para ver seus códigos e maneirismos de tratar a bicha do primeiro andar.

Passaram semanas, nessa paquera, e nas poucas oportunidades que tinham de conversar, acertavam sua visita e sua espera em vão se tornava costumeira. Ele, um guapo mancebo, de corpo talhado pelo trabalho braçal, de olhar sedutor e lábio leporino, cuja dificuldade na fala, deixava-o bisonho, ao tentar se comunicar. Talvez seja possível que, também tenha sofrido, durante sua trajetória de vida, algum tipo de preconceito, por conta de sua fenda palatina, o que gerava um certo reconhecimento de suas dores sociais, porque Dulce também sofrera algo semelhante, em razão de suas orelhas abanadas.

Nesse jogo agonístico representado pela epígrafe, desse texto, em que muitas vezes, assim como na música, Dulce dizia, que ia "pro mato", bem como ele dizia que subiria em sua casa, e ao final e ao cabo, não iam a lugar nenhum. O medo tensionou essa relação, como se Xangô, cantado por Vinícius de Moraes, chamasse Dulce de coitada, por cair no canto de Ossanha, 
traidor. O mato, entre arbustos e folhas, era um lugar inóspito para um sujeito que mesmo sendo do interior, teve seu corpo, riscado por subjetividades de uma Campina Grande urbanizada, que remetia a violência física e simbólica porque às bichas passavam. O "vai vai vai" da música, era a voz de seu corpo pulsante de desejo, sendo provocado, incitado ao movimento por Ossanha, orixá das folhas, o medo de virar um número e purpurina, nas estatísticas dos assassinatos por motivação homofóbica, de ser encontrada morta, banhada de sangue, penetrada não por um falo, mas por estocadas de uma faca peixeira tirada da bainha do vaqueiro, cantava o "não vou", nesse dueto de um corpo disciplinado e de alma medrosa, que a partir de princípios normativos e regulares, encarcerou sua existência. A cerca dessa violência homofóbica que as bichas sofrem, Murillo Nonato (2020), nos coloca que se trata de uma das sanções propostas ao corpo, a partir de seus maneirismos, gestos, falas e vestes que são gatilhos construídos historicamente para a incitação à brutalidade.

O autor fez uma pesquisa sobre as vivências afeminadas numa perspectiva da cidade grande, de uma capital nordestina, Salvador. Essa mesma violência que descreve, para as bichas colaboradoras de sua investigação, poderia ser aplicada a Dulce, enquanto sujeito nascido numa cidade de seus mais de 400 mil habitantes, cujo espaço urbano grassa, tantos outros relatos de brutalidade contra às bichas. Entretanto, em Cubati, há um descontínuo dessa lógica, não que a violência não exista nas cidades pequenas do interior com menos de 10.000 habitantes, não que as bichas vivam em um vale encantado, cujas existências são construídas a partir de experiências hedonistas, em que o sexo, o desejo, o prazer, o gozo, fossem facilmente conquistados. Me parece, que eu não conseguia perceber os códigos de sociabilidade do lugar, que embora seu medo, pudesse a proteger, ele também a impediu do vaqueiro Ihe "comer".

Ainda que muitas lembranças de violências por ela sofridas, quase todas simbólicas, a livrasse do (en)canto que o orixá Ihe propunha, Dulce resolveu encarar o novo, enfrentar a "vida", última palavra da letra da canção. Esse enfrentamento só conseguiu, quando conheceu suas amigas Jacira, Telma, Irma e Irene, pois todas elas viveram essa experiência de deixar desejo e prazer tomarem conta de seus corpos, guardados como segredo por trás 
das folhas de Ossanha, cobertos, muitas vezes, pelo véu da noite. Como Jacira conta neste relato:

[...] aí teve outras experiências com outras pessoas, com outras bichas, que foi no mato, a outra experiência com a bicha, mas só era um boy com as duas, foi tudo assim [...] é [...] porque nesse dia, a gente tipo trocava, como era no mato, era uma pedra enorme, aí uma ia e depois a outra ia [...] e findou, porque é [...] o boy gozou em mim, tá ligado? Não gozou na outra pessoa, mas em mim [...] comigo! (Grifos nossos).

Jacira sempre se mostrou ser um sujeito de poucas palavras, ainda que seu silêncio também falasse. Seu corpo deixava escapar seu desejo, performando um gênero, apresentando ao mundo, uma bicha afeminada e fogosa que adorava o sexo, mesmo que, para escapar das muitas sanções, proibições e tabus, a Jacira e suas amigas, recorriam ao mato, como tática para dar vasão a sua pulsão desejante, experienciando o prazer, que fora proibido por esse dispositivo da sexualidade que sempre tentou impedir seu gozo e o das amigas. A performatividade de gênero, traz em seu interior, a repetição de normas, construídas pelas proibições, tabus estabelecidos e que aparecem em nossos discursos, produzindo o que se nomeia.

O ato performativo da Jacira, produzia o que nomeava, nesse caso, as proibições, quando ela diz: "[...] era no mato, era uma pedra enorme", implicitamente aparecia a negação do sexo entre dois homens, bem como a desautorização desta prática no espaço urbano, tendo que ser escondido, no meio do mato, entre os muitos lajedos, que constituem a paisagem natural da cidade. Observa-se que além do ato proscrito do sexo entre iguais, Jacira diz, em tom de justificativa: "[...] mas só era um boy com as duas".

Havia uma outra camada de negação de seu sexo, no fato dela compartilhar o "boy" com uma bicha amiga. Desta forma, para Jacira e sua parceira, com quem dividia o rapaz, dirimir o interdito, era necessário usarem como tática, esse afastamento de uma delas, enquanto a outra esperava a comparsa, fornicar com o rapaz. A amiga, à espreita, permanecia vigilante, caso alguma presença indesejada pudesse atrapalhar, a transa daqueles sujeitos. A fala de Jacira também é reveladora de um certo jogo do desejo, uma certa competitividade entre as parceiras, que disputavam quem melhor proporcionava prazer ao "boy", quem fosse a mais safada, naquele instante impudico, ganharia o troféu, orgulhosamente verbalizado pela Jaci ao dizer: 
"[...] o boy gozou em mim, tá ligado? Não gozou na outra pessoa, mas em mim [...] comigo!".

Os três se dispersaram pelas brenhas, para não serem vistos saindo do mesmo lugar, juntos. As bichas, voltaram para casa, serelepes. Jacira ainda mais, com a certeza de ter sido melhor, por ter ganho do rapaz com quem transaram, o gozo final, pela performance sexual praticada. Neste ménage à trois, o poder se fez presente, naquele matagal, entre lajedos, seixos e coroas de frade. Essa relação à três, evidenciou o protagonismo de Jacira, bem como a amiga, sendo-Ihe reservada, o papel de coadjuvante, assim como o rapaz do troféu.

Nesta relação de poder, Jacira saiu vitoriosa, não apenas por ter conseguido uma melhor performance quanto ao sexo, como também venceu o "boy" neste jogo de desejos múltiplos, emasculando o jovem heterossexual - pertencente das luzes da cidade, caindo na mandinga de Ossanha, sendo levado ao mato, lugar onde de nada valia, alcunhas do tipo "cabra macho". Pensar esse relato da Jacira, se torna interessante, quando se olha as lutas de forças que estão em jogo. Michel Foucault (1998, p. 12) dizia que esta genealogia de "um mundo de coisas ditas e queridas", tem em suas tramas "invasões, lutas, rapinas, disfarces, astúcias", que foram descritas na narrativa de Jacira, uma história, que não é apenas dela, mas de muitas bichas citadinas do interior, como diz Durval Albuquerque Jr. (2019), que sujeitos biografados, neles se encontram outros, marcados pela diferença, a partir da descontinuidade que existe entre o passado e o presente.

Se Jacira em seu relato, não era apenas uma e sim muitas das bichas do interior, a experiência da Telma, também fora repleta de astúcias, que driblaram esse dispositivo de sexualidade que nomeava e as colocava como sujeitos abjetos, mas que não conseguiam impedir o seu prazer. Ao conhecer o sexo e mesmo, já experiente, em seus relatos, um passeio pela cidade, desacompanhada de suas amigas, desfrutando de um lampejo de tempo curto, rápido, veloz, aproveitando uma brecha de oportunidade, Telma vivenciava suas relações bichas. Assim, ela descreve suas aventuras:

[...] eu mais durante a noite, porque quando eu ia pra o sítio, pra Prainha, aí eu tinha [...] que eu ia pras novenas, gata, eu ia pras novena, mas nessa época que eu comecei o lance com o João, tá ligado? [...] e João era muito doido, tá entendendo? De pegar a moto e a gente ia de moto, saia pros canto, tá entendendo? E era numa carreira, que era babado, e naquela época o povo da família nem desconfiava, ninguém 
desconfiava naquela época [...] aí ia buscar alguma coisa no sítio, que esqueceu, alguma coisa. Aí a gente sempre ia de moto, tá entendendo? Aí era uma coisa de Aventura, gostava! Num vou mentir que eu gostava! No mato no mato! tá entendendo? A questão também, muitas de moto, de sair lá também, para o sítio e sair também de moto, eles heteros, casados, exatamente! (Grifos nossos).

A noite podia ser linda, podia ser louca, podia ser útil, e as bichas não conseguiam se desconectar dela, com raríssimas exceções, seus encontros sexuais e amorosos, aconteceram no breu, na escuridão do mato, onde só era permitida, a luz dela, da solitária lua, cujo segredo de seu desejo, confidenciava a ela, fazendo deste encontro notívago, uma experiência única, de tesão, de tensão. O ardor dos corpos de Telma e João, fazia as estrelas rirem deles que, ouviam cochichar de sua intimidade, como na poesia de Olavo Bilac, ruborizadas com o enxerimento desses rapazes, apressados em cima de uma moto, correndo numa estrada de terra, num sítio afastado da zona urbana, tentando encontrar o lugar perfeito e parar, se despir, se desnudar de seus preconceitos, das marcações de gênero de seus corpos - "[...] eles heteros, casados", marcações essas, que eram guardadas na casa deles, cujo "[...] povo da família, nem desconfiava".

A cerca do uso de um tempo curto para amar, Durval Albuquerque Júnior (2010), numa perspectiva ética, nos coloca que, já nos anos 1980, Michel Foucault em entrevistas, falava ao seu público sobre, o tempo curto e fugidio das relações afetivas entre homens, cuja velocidade dos transportes e comunicação, corroborava uma sensibilidade de sujeitos que não tinham tempo a perder, sendo inventivos em fazer das escapadelas, da missa, da reunião social, dos encontros abertos, das festividades, uma fresta para a maximização desses poucos minutos, tornando-os um tempo lento que só as bichas conseguem fazer. Tempo curto em que um encontro às escondidas, para um namoro, uma transa, um sexo casual, era muito, para sujeitos que são considerados abjetos, por não se encaixarem na cisheteronormatividade.

João tinha pressa, correndo desembestado em sua motoca sem placa, enquanto Telma suspirava de encantamento, representado em sua fala quando diz: "[...] João era muito doido [...] e era numa carreira, que era babado". Ela estava entregue ao risco presente na alta velocidade, entregue aquele tempo curto, para no tempo do amor, tornar-se lento, ao ponto de não perceber o seu fim, ao ponto de ter esquecido a novena, que tentara marcar 
seu corpo ou sua alma. Telma escupia sua estética da existência, construindo uma ética com o sagrado, cujo Deus e Ave Maria, a convidava sempre às novenas, cumprindo seu ritual de devoção, que não era anulado com a velocidade profana da moto de João, mas o sagrado e o profano, se uniam nessa experiência de sensibilidades, por vezes repetida.

Segundo Sandra Pesavento (2014), a História Cultural ao se preocupar com as sensibilidades, trouxe à luz de Clio, histórias de vidas esquecidas, vidas silenciadas, vidas que não importavam, vidas abjetas, vidas subalternizadas, inclusive por uma historiografia que, quando realizava a escrita de biografias, fazia dos grandes vultos, dos grandes nomes da História, excluindo e nomeando os outros como marginais, porque postos à margem de uma história oficial, não interessava à leitura nas escolas, nos centros acadêmicos, nas universidades, falar sobre os sentimentos, sensações e emoções destes sujeitos.

Pensar uma história das sensibilidades, a partir da representação dos corpos de bichas do interior, é evocar não somente suas condições de assujeitamento numa terra árida, cujo mato seco, é característica preponderante de um território habitado por calangos, tacacas, tamanduás, tejos e timbus. Bichos que podem ser excêntricos para citadinos das capitais e grandes cidades, mas que são tão comuns quanto as bichas que habitam esse texto.

Suas condições de assujeitamento, são muito parecidas com as que disciplinam os corpos de outras bichas, no entanto, seus sentimentos, emoções e valores são marcas indeléveis, de uma estética esculpida no mato, em cima de lajedos, cujas existências poderiam ser lúgubres, mas guardam em seu interior, uma reserva de alegria, de risos soltos, a partir da amizade, que as uniu, nesse elo de resiliência. Dentre tantas histórias sensíveis, noturnas e silenciosas, sua patuscada, deixava rastros de terra, de sêmen, de saliva, do lubrificante da camisinha em suas mãos e outras partes de seus corpos, formando um arquivo picante, quente, apimentado. Irene destaca os lugares pelos quais, suas partes pudendas eram expostas à escuridão:

[...] tem aquela questão né, da vontade da ocasião [...] então já fiz muito sexo gostoso durante o dia, como durante a noite. Aqui em Cubati, costumava mais ser durante a noite, né? Porque tinha a questão da ocasião, né? que influenciava muito nisso, por exemplo, terminava uma boate, terminava a boate, aí elas iam é, transar, então nesse sentido, aqui em Cubati, era mais durante a noite, mas não era porque eu ache 
mais prazeroso, durante a noite, mas tinha muito esse lance das oportunidades, em que aconteciam esses encontros amorosos e sexuais [...] com certeza, gata [...] e daquelas que não queriam também se assumir, essa ocasião era perfeita para isso, transar em mato, Campo de Palmeiras, Enduro (Grifos nossos).

Numa perspectiva foucaultiana, há nos relatos, um dilema posto para uma história bicha, uma história viada, porque usávam o sexo, em suas digressões noturnas e bucólicas, não para revelar seus segredos mais inconfessos, ainda que seus corpos-arquivos, deixassem rastros de uma noite de prazeres e afasias. O sexo esteve presente, como a linha que costurou suas relações de amizade, mesmo que discursos pululantes de hipocrisia, condenasse as práticas das bichas, seu desejo. "[...] transar em mato, Campo de Palmeiras, Enduro", como dito pela Irene, era o que muitas vezes restava, da solidão de vidas, cujas relações eram negadas à luz do dia, e que foram ressignificadas no silêncio da noite. Sobre o barulho deste silêncio, Thiago Oliveira e Helder Thiago Maia (2019), comenta que o sexo pode ser uma questão menor para muitos, para uma historiografia que ao ignorar as práticas sexuais, tenta também silenciá-las, porque elas dizem, através de suas minúcias e seus detalhes, algo de genuinamente revelador, não de uma sexualidade escondida em um armário, mas uma maneira de viver, uma ética que alinhava um cuidado de si, a partir de relações que são construídas no/pelo silêncio tanto das bichas quanto de outras sexualidades dissidentes, como as que aparecem neste texto, enquanto coadjuvantes.

Os autores, conferem ao texto, a ideia de que não importa aqui o sexo, ainda que as narrativas das bichas do interior, seja "algo genuinamente revelador". Interessa-nos pensar esse sexo, como uma linguagem de seus corpos, de suas relações afásicas, ligeiras, gozadas em instantes curtos, temerárias das falas alheias, por se tratar também de um dispositivo que colonizava suas carnes trêmulas. Por outro lado, esse sexo linguagem, também pode ser um sexo tecnologia de muitas experiências tanto de assujeitamentos, quanto de astúcias de seus modos de existência, aproveitando aquilo que Irene enuncia como "a questão da ocasião, né?".

Telma, Irma, Irene, Jacira e Dulce Veiga, tem em seus relatos de suas práticas sexuais, a elaboração de suas astúcias, táticas, para gerir seus corpos e desejos, construindo discursos, cujo sexo operacionaliza e (des)estabiliza suas vidas sociais, entre elas e a partir de suas outras relações construídas 
paralelas às delas. Como a história do vaqueiro leporino que vai, ou não vai, sobe ou não sobe no primeiro andar, a gozada do "boy" na Jacira, cuja parceira de transa, ficara desapontada por não ter ganho o "troféu", o uso das moitas, brenhas, lajedos, mato e a fuga das luzes da cidade, na velocidade da moto que levava Telma, também para o "abate", logo após as novenas, cujas escapadelas, eram sua razão "primeira" de sair de casa.

Nesse sentido João Silvério Trevisan (2018) postula que, as homossexualidades à brasileira são paradoxais porque elas não se movimentam no sentido de uma militância política, mas se movem a partir do desejo e de uma generosidade entre seus pares, conferindo um cuidado de si, cujas redes de sociabilidade das bichas, transgredem as instituições cisheternormativas como o casamento e a família, provocando rachaduras nesses modelos que, teoricamente não aceitam nenhum tipo de rearranjo em seu entorno. Dito de outra forma, as bichas de Cubati, enquanto recorte desta pesquisa, mantem relações com homens que vivem relações conjugais com mulheres, que possuem famílias tradicionais, mas que também usam do tempo curto, das escapadelas, para fazer fruir seu desejo por outros homens, por outros cus que não sejam de suas esposas.

A "vivência guei brasileira" assim como fala João Silvério Trevisan, sempre foi vista pelas lentes de estudiosos que viam, percebiam e falavam a partir dos grandes centros urbanos, das médias ou grandes cidades, até mesmo pela lógica dos deslocamentos que um sem-número de bichas, saiam dos lugarejos, do interior, em busca de um espaço, onde pudesse construir suas relações de amor, de desejo, sem serem punidas por esse dispositivo da sexualidade, que sempre tentou educar para práticas educativas do machismo, da misoginia, da homofobia. A Dulce Veiga do Caio Fernando Abreu e a deste texto, construída e vivida por uma bicha do interior nordestino, fez um deslocamento contrário, saindo de uma cidade de porte médio, para Cubati. Privilégio esse, que não foi exclusividade minha. A Irma, saiu de Cubati, e fez outros deslocamentos por cidades pequenas, trepando, conhecendo outras bichas, namorando e assim como todas, construindo suas estéticas da existência.

Nossa amiga Irma, diferente da Jacira, Telma, Irene e Dulce, talvez não tenha a mesma "vocação" para ser puta, quanto as outras. Participar de algum tipo de putaria, para ela, causou-lhe algum constrangimento. De alguma 
forma, isto é revelador, desse "transbordamento barroco" que Trevisan nos falou, um paradoxo inscrito em nossos corpos, uma forma de assujeitamento, permeado por muitas astúcias que negavam esse disciplinamento pelo qual, todas nós passamos com nossas existências. No entanto, venceu a "impetuosidade do desejo" e fomos, mais uma noite, no "campo do Palmeiras", ser essas devassas no paraíso, como relata "cheia de dedos", a Irma:

[...] assim, não sei se isso é considerado, né mas foi aquele momento (risos) [...] eu acho que foi [...] só teve um momento real, que eu considero como orgia ou troca de casal, né? Orgia, no real, né? Que acho que foi aquele momento com vocês: o único! O único! Naquele momento eu achei, né? Que eu nunca passei a dividir nada com ninguém, foi bem estranho! Curiosidades eu tenho, mas até hoje eu acho que é muito [...] parte muito da pessoa, do momento, não sei [...] quem sabe no futuro, né [...] eu tenha outras percepções, né? Eu tenho um certo receio, né por exemplo, dessa questão de tudo bem de troca, mas de orgia, né? Vai existir pessoas que vão se identificar com outras e podem não ocorrer o que você deseja, talvez eu pense muito nisso e não no momento em si, na euforia do momento [...] que pra vocês, vocês conviveram muito, uma época, né? Esse troca! Foi quase o que a gente fez naquele dia, cada um foi (Grifos nossos).

A Irma, guarda uma certa semelhança com Dulce, quanto aos seus armários formadores de suas identidades, não como algo estático, parado, nem o próprio armário é inerte, ele sempre está se reconfigurando nas existências de quem os coabita, como afirma Eve Sedgwick (2007), pela necessidade de "novos levantamentos, novos cálculos, novos esquemas e demandas de sigilo ou exposição". Em sua fala, as reticências são muitas, caracterizadas por silêncios pausados, que evidencia o paradoxo dito por Trevisan (2018), misturando fascínio, desejo, repulsa, por algo que foi feito coletivamente no campo do Palmeiras, com um "boy", para usar a expressão da Jacira.

Segundo Murillo Nonato (2020), desde quando o conceito de homossexualidade fora construído no século XIX, o armário se configurava também como uma tecnologia para a opressão dos sujeitos homossexuais que, mesmo não abdicando de seu desejo, deveria em contrapartida, escondê-lo, omiti-lo e para isso acontecer, desde crianças, as bichas aprendem atos performativos que ajudam nessa árdua missão que lhes foram inculcadas, a da repressão, da marginalização de seu desejo. Seus corpos não poderiam deixar escapar, aquilo que se vigiava constantemente pelo dispositivo de sexualidade. O armário presente nestes sujeitos desde sua tenra 
infância, reforça os laços cisheteronormativos e essa divisão binária macho X bicha, que coloca de um lado aqueles que são ativos, cujos corpos, se restringem a seus falos penetrantes e do outro lado, sujeitos passivos, prontos para devolver da merda, a parte metonímica dos sujeitos que dizem ignorar o desejo por outros buracos.

O autor descreve a partir do rigor acadêmico, aquilo que Irma sintetiza no fragmento de sua fala, representando esse viver discretamente, operacionalizando com cuidado sua sexualidade, ainda que ao fazerem isto, reforçavam a ideia de que a heterossexualidade era "normal/natural/saudável". Apesar disto, o desejo as impulsionava ao desmantelo da norma, à busca de astúcias criativas, pelas quais conseguiam viver, sentir na pele, no pelo, na boca, no cu, os corpos de outros homens. E foi assim, quando estavam todas na boate Styllus, costume nosso, dos fins de semana, de juntar a turma, fazer um "esquenta", que geralmente era na casa da Dulce, compravam algumas bebidas, e ficavam parte da noite na "casa das bonecas".

Por volta das 22 horas, desciam para a casa noturna, que pertencia a um dos homens, à época, mais cobiçados da cidade. Todas flertavam com ele. Um sujeito cisheteronormativo, que ainda que não pudessem afirmar, ouviam histórias de suas TRANSgressões da heteronormatividade. Na Styllus, já eram conhecidas, todes, todas e todos olhavam para a turma da "casa das bonecas", quando elas chegavam. Nesse caldo cultural de nosso país, as práticas educativas da sexualidade, como o machismo, construíam uma divisão de papeis sexuais que definiam os lugares para nós, naquele lugar, como as bichas afeminadas, que estavam à procura dos machos, que as comessem. Todas, todes e todos naquela boate, eram sujeitos do desejo, ébrios de álcool e outras drogas, pela noite, fumaça de gelo seco, e uma música que nem sempre, fazia parte de repertório musical das bichas, mas que elas adoravam ouvir, rir, dançar. A boate, teve vida curta $^{8}$, e dela, tem-se um repertório vasto

\footnotetext{
${ }^{8}$ Após o incêndio da boate Kiss, numa cidade do interior do Rio Grande do Sul, em janeiro de 2013, evento que foi muito explorado pela mídia e deixou o país em comoção, sua repercussão foi sentida em nosso interior, num outro extremo do país. Agências reguladoras, a mando do governo estadual, começaram a fazer muitas exigências para o funcionamento das casas noturnas locais. Seus donos, por sua vez, não tinham dinheiro suficiente para o investimento em segurança, que estavam exigindo à época e as boates da região do curimataú começaram, lentamente, a fechar. Além deste fato, a última "pá de terra" para o fim definitivo da Styllus, foi um assassinato ocorrido na frente do estabelecimento, onde um rapaz da cidade de São
} 
de muitas histórias, dentre elas, essa que a Irene começou a falar com meias palavras.

Diziam que a boate estava "boa", quando tinha festa, ou quando tinha muita gente. Conseguiam identificar os citadinos de Cubati e os forasteiros das cidades vizinhas, que sempre vinham à boate. Numa dessas noitadas, elas falaram com um rapaz com quem todas, ou a maioria, já havia tido alguma relação. E pediram a ele, que conseguisse amigos, para as bichas. Nenhum amigo dele, havia concordado em ir, até porque esse ritual, era feito rotineiramente e sempre conseguiam muitos "esquemas" para todas as bichas. Nessa noite, apenas esse sujeito concordou em sair da Styllus, quando acabasse o expediente da boate, e irmos para algum lugar, transar.

Era por volta de uma da manhã, quando a boate acabou. Geralmente os frequentadores, ficavam no entorno da praça, terminando suas doses, fumando seus baseados, outros combinando suas saídas de moto em grupo, para os sítios distantes e as bichas, bem faceiras, ficavam em um banco da praça, estudando com um olhar atento, todos esses movimentos, sempre de olho naquele com as quais haviam acertado o encontro, na penumbra da boate. Naquele instante, acontecia uma troca de olhares fugidios, marcadamente uma comunicação inteligível desses sujeitos do desejo. Então decidiram ir ao campo do Palmeiras, isso porque eram muitos cus para uma única pica, e em comum acordo, resolveram encontrar o rapaz, para ao menos fazer uma "gravação".

Todas elas se achavam ótimas cantoras e quando pegavam num microfone, não queriam mais largar. Combinaram todas de irem separadas para o campo, sem chamar atenção, porque ainda havia muitas pessoas pela praça, no fim da noite. Chegando no local combinado, começaram a fazer sexo oral no rapaz, que ficou de pé, em silêncio, enquanto as bichas, num revezamento 5x7, matavam um pouco, a sede de seu desejo. Depois do gozo dele, elas se dispersaram também silenciosas, com a sensação de que as faltavam algo. Saia do mato com uma vontade de chegar em suas casas e descansar, dormir e esquecer ao menos, por aquela noite, a incompletude.

Sobre este episódio, Durval Albuquerque Júnior (2010) a partir de uma estética da existência proposta por Michel Foucault, coloca que o ato sexual

Vicente do Seridó, levou tiros de arma de fogo à queima roupa. A boate da praça, fechou suas portas em dezembro de 2005. 
para as bichas, é usado de uma maneira a tentar suprir suas solidões, porque a estes sujeitos, é negado o modelo do amor romântico ou o padrão de relacionamento duradouro para os heterossexuais que é o casamento, ainda que esse modelo, seja agenciado de inúmeras maneiras tanto por bichas quanto por outros sujeitos. Quando Cazuza nos anos 1980, cantava que adorava seu amor inventado, é dessa arte inventiva de lidar com situações que marginalizam corpos e desejos desses sujeitos subalternizados, que as bichas constroem seu devir, ainda e felizmente, não concluído tal projeto, cuja grande barreira a ser quebrada nesta subcultura, seria desconstruir essa relação metonímica que as bichas tem com o falo como o corpo, de seus amantes de ocasião.

\section{Considerações finais}

As bichas de Cubati, não se resumem a Telma, Irma, Irene, Jacira e Dulce. Elas são muitas, dentro e fora do armário. No entanto, as que aparecem aqui nesse texto, falando de suas carências, solidões e idiossincrasias, semelhanças e diferenças entre elas, são vozes e corpos que nasceram para serem silenciados, para não falar de si nem das outras, rompendo o silêncio pelo qual assujeitaram seus desejos. Falar de si, além de ser um ato de coragem, é um ato político, sobretudo num tempo em que o autoritarismo à brasileira, espreita os seus gemidos, o seu gozo. As bichas da "casa das bonecas", tantas vezes silenciadas, são o eco na voz de Maria Bethânia "[...] eu não sei dos mil homens na cama", dizendo de seu exílio, imposto a elas, e a todas as bichas mundo à fora. Um exílio que começa desde o nascimento, passando pela docilização de seus corpos, promovido pelas instituições das quais são submetidos.

Enquanto homens "falhos", "incompletos", tais instituições, pelo olhar sensível das bichas, também demonstram sua incompletude para com elas. As chamam de imorais, de pouca vergonha, promíscuos e não conseguem enxergar as suas dores, porque seus olhos só veem o seu sexo, como se estivessem reduzidos a este elemento constitutivo de suas vidas. De alguma maneira, as bichas de Cubati, internalizaram isto, passaram a ser, para a sociedade cisheteronormativa, sujeitos metonímicos, cuja única parte da qual nos enxergam, totalizam e conformam ou deformam os nossos corpos. Esse 
exercício de pensar e escrever sobre as bichas do interior, é uma tentativa de perceber a experiência delas a partir de seus silêncios, de suas pausas, de seus olhares fugidios, de seus medos e mostrar o quanto elas foram e são inventivas na construção de suas estéticas da existência.

Sobre a escrita de uma história viada, Durval Albuquerque Júnior (2019) nos coloca a necessidade de se repensar a escrita da história, para esses sujeitos subalternizados, porque suas regras de produção, códigos e modelos, continuam reforçando a marginalização de corpos que lhe foram ensinados a permanecer quietos para não desmunhecar, que tais sujeitos não falassem de seus cus, e muito menos os historiadores, devessem colocar palavras tão torpes que escandalizassem ou sujassem seus textos, com a merda-símbolo das bichas que passam cheque, porque destas não se interessa ler sobre seus sonhos, desejos, afetações, quando no máximo, para muitos, o que interessa são aquelas que denegam tudo o que há de erótico nelas, engessando seus corpos nos armários dos quais, são uma presença formadora, desde suas infâncias.

Jacira, Irene, Irma, Dulce e Telma saíram de seus armários e lutaram constantemente contra essa presença formadora, juntas, elas passaram a ser um arco-íris, um fenômeno ocorrido quando o sol brilha sobre gotículas de água suspensas no ar. Sim, à luz do dia. Elas não são signos da noite, apesar de gostarem dela, apesar de precisarem de seu breu, para aliviar suas tensões, na rapidez do percurso da lua, evitando o alvorecer, evitando que sejam vistas subindo suas calças, no campo do Palmeiras, descobrindo seus segredos, sendo olhadas com reprovação, sendo chamadas de abjetas. Se aqui, existia entre um segredo, esse não era sobre as suas homossexualidades, mas sobre suas solidões, que deixaram de existir, a partir de seus encontros. Houve temporalidades em que discursos médicos, jurídicos, políticos e policiais colocavam para as homossexualidades, como única problemática a articular saberes, fosse o desejo como um segredo a ser desvendado e Michel Foucault (1981) nos possibilitou pensar, através de seus cursos e entrevistas, já nos últimos anos de vida, uma outra ética, que usasse da sexualidade para chegar a inúmeras possibilidades de relações, que fossem criativas e que mostrassem ao mundo, uma outra arte de viver, uma estética da existência a partir da amizade como modo de vida. 
A "casa das bonecas" foi o lugar do encontro de cinco bichas que se reconheceram ao bater os olhos umas nas outras, assim como todas fazem, elas fizeram leituras de suas carnes, de seus atos perfomativos e viram suas "almas" encarceradas em corpos, passando a dividir a dor e o prazer de ser quem são. Construíram seus modos de vida, dividindo "boys", cigarros de maconha, o teto de uma casa, o mato. Construíram laços de solidariedade, onde a amizade era esse lugar do encontro, essa relação desejável, de amar, de devir bicha.

\section{Referências}

ABREU, C. F. Caio Fernando Abreu: o essencial da década de 1990. Rio de Janeiro: Nova Fronteira, 2014.

ALBUQUERQUE JR, D. M. de. A invenção do Nordeste e outras artes. São Paulo: Cortez, 2009.

ALBUQUERQUE JR, D. M. de. História: a arte de inventar o passado. Curitiba: Appris, 2019.

ALBUQUERQUE JR, D. M. de. O tecelão dos tempos: novos ensaios de teoria da História. São Paulo: Intermeios, 2019.

ALBUQUERQUE JR, D. M. de. Nordestino: uma invenção do falo. Uma história do gênero masculino (Nordeste - 1920/1940). Maceió: Edições Catavento, 2003.

ALBUQUERQUE JR, D. M. de. Amores que não tem tempo: Michel Foucault e as reflexões acerca de uma estética da existência homossexual. Revista Aulas, Campinas, n. 07, p. 41-58, 2010.

CONNELL, R.; MESSERSCHMIDT, J. W. Masculinidade hegemônica: repensando o conceito. Revista Estudos feministas, v. 21, n. 1, pp. 241-282, 2013.

FOUCAULT, M. História da sexualidade 1: A vontade de saber. São Paulo: Paz e Terra, 2014.

FOUCAULT, M. História da sexualidade 3: O cuidado de si. São Paulo: Paz e Terra, 2017.

FOUCAULT, M. Microfísica do poder. Rio de Janeiro: Graal, 1998.

FOUCAULT, M. Vigiar e punir: nascimento da prisão. Petrópolis: Vozes, 1987.

FOUCAULT, M. A ordem do discurso. Rio de Janeiro: Loyola, 2012.

FOUCAULT, M. Entrevistadores. Gai Pied, n. 25, pp. 38-39, 1981.

FOUCAULT, M. Sex, Power and the Politics of Identity. The Advocate, n. 400, p. 26-30, 1984.

GREEN, J. Além do carnaval: a homossexualidade masculina no Brasil do século XX. São Paulo: Editora Unesp, 2019. 
MISKOLCl, R. Teoria Queer: um aprendizado pelas diferenças. Belo Horizonte: Autêntica, 2020.

NONATO, M. Vivências afeminadas: pensando corpos, gêneros e sexualidades dissidentes. Salvador: Editora Devires, 2020.

OLIVEIRA, T. Práticas sexuais: itinerários, possibilidades \& limites de pesquisa. Salvador: Editora Devires, 2019.

SEDGWICK, E. A epistemologia do armário. Cadernos Pagu. Campinas, v. 28, 2007, pp. 19-54.

VERAS, E. F.; PEDRO, J. M. Os silêncios de Clio: escrita da história e (in)visibilidade das homossexualidades no Brasil. Revista Tempo e Argumento, Florianópolis, v. 6, n.13, pp. 90-109, set./dez. 2014.

VERAS, E. F.; PEDRO, J. M. Outras histórias de Clio: escrita da história e homossexualidades no Brasil. SOUSA NETO, M. R.; GOMES, A. R. História e teoria queer. Salvador: Editora Devires, 2018. 